\title{
Use of Sugarcane Bagasse and Industrial Timber Residue in Particleboard Production
}

\author{
Bruna B. R. Yano, ${ }^{\mathrm{a}}$ Sergio A. M. Silva, ${ }^{\mathrm{b}}$ Diego H. Almeida,${ }^{\mathrm{c}}$ Vinicius B. M Aquino,,${ }^{\mathrm{d} *}$ \\ André L. Christoforo, ${ }^{\mathrm{e}}$ Edson F. C. Rodrigues, ${ }^{\mathrm{e}}$ Antônio N. Carvalho Junior, ${ }^{\mathrm{f}}$ \\ Adriano P. Silva, ${ }^{f}$ and Francisco A. R. Lahr ${ }^{\mathrm{g}}$
}

\begin{abstract}
Use of lignocellulosic materials in particleboard has turned into an alternative for the reuse of such materials, which are abundant and may have precarious disposal techniques. The present study fabricated particleboards using industrial sawmill waste from tropical hardwoods (a mix of species) and sugarcane bagasse with castor oil-based bicomponent polyurethane resin and evaluated the influence of the incorporation of sugarcane bagasse $(0,10,20,30,40$, and $50 \%)$ on the physical and mechanical properties of the composites. The particleboards were produced according to the Brazilian Standard ABNT NBR 14810 (2018), and performance requirements were assessed using Brazilian and international standards. Some of the particleboards met standardized requirements, with Treatment 5 (50\% sawdust and $50 \%$ bagasse) showing better performance, indicating the possibility for use indoors in dry conditions. The addition of sugarcane bagasse increased dimensional stability of particleboards when compared with panels manufactured with timber residue. Statistical analysis indicated the percentage of bagasse was significant, increasing physical and mechanical properties when compared with the reference treatment.
\end{abstract}

Keywords: Industrial sawdust; Tropical hardwoods; Particleboard; Castor oil resin; Sugarcane bagasse

Contact information: a: Department of Civil Engineering, West São Paulo University, Presidente Prudente/SP, Brazil; b: Department of Civil Engineering, São Paulo State University, Ilha Solteira/SP, Brazil; c: Department of Civil Engineering, Federal University of Rondonia (UNIR), Porto Velho/RO, Brazil; d: Araguaia Engineering Institute, Federal University of Southern and Southeastern Pará (UNIFESSPA), Santana do Araguaia/PA, Brazil; e: Department of Civil Engineering (DECiv), Federal University of São Carlos, São Carlos/SP, Brazil; f: Department of Civil Engineering, Federal University of Minas Gerais (UFMG), Belo Horizonte/MG, Brazil; g: Wood and Timber Structures Laboratory,

Department of Structural Engineering, São Carlos School of Engineering of São Carlos, University of São

Paulo (USP), São Carlos/SP, Brazil; *Corresponding author: aquino.vini@ hotmail.com

\section{INTRODUCTION}

The utilization of wood engineered products, such as medium-density particleboard (MDP), medium-density fiberboard (MDF), and oriented strand board (OSB), has increased as an alternative to timber use in structures, manufactured products, furniture, and other items (Hiziroglu et al. 2008; Souza et al. 2014; Zhou and Pizzi 2014; Fink et al. 2018; Ribeiro et al. 2019). It is possible to highlight particleboards (PB) among wood products that use processed wood and resin under conditions of elevated temperature and pressure (Silva et al. 2015; Nascimento et al. 2016; Ihnát et al. 2017; Lima et al. 2018).

To make particleboard manufacturing greener, an alternative is to incorporate lignocellulosic waste in particleboards (Hazrati-Behnagh et al. 2016; Akgül et al. 2017; Fiorelli et al. 2019; Ribeiro et al. 2019), such as corn cob (Paiva et al. 2012), flax and hemp 
(Sam-Brew and Smith 2017), poppy husks (Khazaeian et al. 2015; Kusumah et al. 2017), bamboo (Melo et al. 2014; Valarelli et al. 2014), and sugarcane bagasse (Hazrati-Behnagh et al. 2016; Oliveira et al. 2016; Fiorelli et al. 2018; Sugahara et al. 2019).

Brazil has a large sugarcane production, with around 620 million tons annually (CONAB 2019). After sugarcane is manufactured for sugar and ethanol, a huge amount of bagasse is produced, with a major part being used to produce energy by burning the waste (Indústria Brasileira de Árvores (IBÁ) 2017). This process releases greenhouse gases into the atmosphere. A cleaner alternative to reuse such waste could be its use in wood panels.

Additionally, Brazil owns the largest vegetal cover on the world, with 494 million hectares on its mainland (Steege et al. 2016; Beech et al. 2017). With a large forest cover, wood is used to manufacture furniture, sports equipment, and structural members (Christoforo et al. 2017). In wood manufacture, tree bark and branches are cut from trees to obtain timber and lumber while also producing a considerable amount of wood waste in sawmills, which is not used in industrial processes (Hofsetz and Silva 2012). Such waste has impurities, demanding classification to be used in panel production.

In particleboard production, resin is an important component due its influence on physical and mechanical properties of the final wood product, including grammage and chemical composition. Commercial resins, such as urea-formaldehyde and phenolformaldehyde, release formalin gas during fabrication processes, which is toxic to humankind (Pan et al. 2007; Muttil et al. 2014; Kusumah et al. 2017). A natural and sustainable alternative is the use of a castor oil bicomponent polyurethane resin (PU), which uses oil from ecological sources (Ferro et al. 2015; Fiorelli et al. 2018; Bertolini et al. 2019a; Sugahara et al. 2019).

Use of particleboards for thermal and acoustical insulation has gained popularity due to their porosity. The presence of air in internal voids provides high thermal resistance and great acoustic absorption, providing environmental comfort for users (Bertolini et al. 2019b).

The present research aimed to evaluate some physical and mechanical properties of particleboards manufactured with wood waste (a mix of species) collected from industrial sawmills, sugarcane bagasse, and castor oil-based bicomponent polyurethane resin, making it possible to verify the application potential of these materials based on the standard requirements.

\section{EXPERIMENTAL}

\section{Materials}

The particleboards were made from industrial sawmill waste from Cariniana micrantha (Tauari), Goupia glabra (Cupiúba), Vochysia guianensis (Cambará), Tabebuia Alba (Ipê), and Apuleialei ocarpa (Garapa) wood species with moisture content of 11\%, and sugarcane bagasse, which was collected from sugar and alcohol plants from the region of São José do Rio Preto, São Paulo, Brazil. The value of moisture content is close to what is disclosed in the literature for Pinus and Eucalyptus particles and PU resin (Varanda et al. 2013; Shirosaki et al. 2018). Moreover, this moisture value does not demand any further drying process, saving energy in the manufacture process. The bagasse was dried in a greenhouse for $72 \mathrm{~h}$ at $60 \pm 2{ }^{\circ} \mathrm{C}$, until a moisture content of $8 \%$ was reached. The resin used was the castor oil-based bicomponent polyurethane resin with polyol $\left(1.2 \mathrm{~g} / \mathrm{cm}^{3}\right)$ made from castor oil and polyfunctional isocyanate $\left(1.24 \mathrm{~g} / \mathrm{cm}^{3}\right)$ in a $1: 1$ proportion (polyol 
and isocyanate) (Ferro et al. 2015). The adhesive proportion utilized to manufacture panels was $10 \%$ wood particles mass (Sugahara et al. 2019).

\section{Methods}

The pretreatment of industrial sawmill consists of sifting the timber sawdust to separate it from various residual impurities that are not sawdust, such nails, screws, bolts, and rocks (Fig. 1a). This selection was made using a sieve set with meshes of 12.5, 9.52, $6.36,4.36$, and $2.36 \mathrm{~mm}$ (Fig. 1b). Sugarcane bagasse was crushed to reach 2-mm to 4-mm granulometry. Table 1 presents the treatments to evaluate the influence of sawdust and bagasse on the physical and mechanical properties of the particleboards.

Table 1. Treatments for Particleboards

\begin{tabular}{|c|c|c|c|}
\hline Tr & Sawdust (\%) & Bagasse (\%) & Total Mass (g) \\
\hline Ref. & 100 & 0 & 1280 \\
\hline 1 & 90 & 10 & 1280 \\
\hline 2 & 80 & 20 & 1280 \\
\hline 3 & 70 & 30 & 1280 \\
\hline 4 & 60 & 40 & 1280 \\
\hline 5 & 50 & 50 & 1280 \\
\hline
\end{tabular}

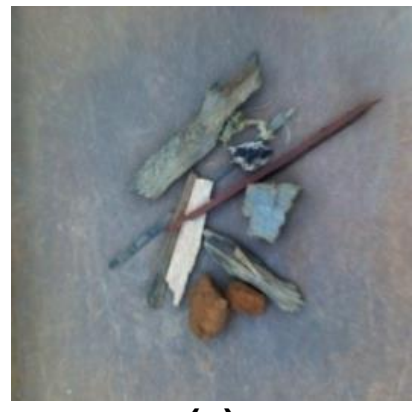

(a)

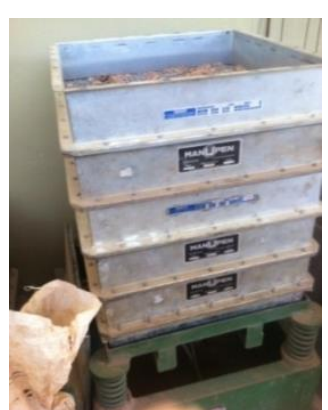

(b)

Fig. 1. Objects separated on sawdust sift (a); Sieve set with vibratory device (b)

After the first sifting of the sawdust, the granulometric composition was analyzed, determining the fineness module for the mixture with industrial waste and bagasse using sieves $6.30,4.76,2.38,1.19,0.595,0.297,0.149$, and $0.075 \mathrm{~mm}$ to evaluate how the mixture behaves, particle size distribution, and the number of fines in the mixture.

Polyurethane resin was mechanically homogenized with wood particles and sugarcane bagasse, and the mixture was then taken to mold the particle mattress to a prepressing of 0.015 MPa pressure. Then, the panels underwent a hot pressing (Model PHH 80T; Capacity 80 t, PHS, Araraquara, Brazil) of $3.12 \mathrm{MPa}$ at $100{ }^{\circ} \mathrm{C}$ for 3 min followed by pressure relief for $30 \mathrm{~s}$ aiming towards gas elimination to avoid bubble formation on panels and a final $7 \mathrm{~min}$ at last on pressure (Sugahara et al. 2019).

For each treatment, five panels were produced with nominal dimensions $40 \mathrm{~cm} \times$ $40 \mathrm{~cm} \times 1 \mathrm{~cm}\left(1600 \mathrm{~cm}^{3}\right)$. After particle selection and consideration of heterogeneity, each treatment was evaluated by considering the moisture content (MC) of sawdust and bagasse and the final mixture used on each treatment, as displayed in Table 2. Mixture moisture contents were evaluated by measuring the initial mass, then taking this mixture to oven at $103 \pm 2{ }^{\circ} \mathrm{C}$ for $10 \mathrm{~h}$ until the difference of mass are equal to zero. Then, the final mass of 
the mixture was compared to the initial mass of mixture before oven drying. The difference of mass is the moisture content, displayed on Table 2.

Table 2. Moisture Content for Each Proposed Treatment

\begin{tabular}{|c|c|c|}
\hline Tr & Total Mass (g) & Mixture Moisture Content (\%) \\
\hline Ref. (0) & 1280 & 11.32 \\
\hline 1 & 1280 & 8.66 \\
\hline 2 & 1280 & 7.85 \\
\hline 3 & 1280 & 6.89 \\
\hline 4 & 1280 & 6.38 \\
\hline 5 & 1280 & 6.56 \\
\hline
\end{tabular}

Observing Table 2, sawmill residue and bagasse exchanged humidity, influencing the moisture content of the mixture. Considering these values, the use of castor oil-based polyurethane resin is acceptable, and this adhesive admits moisture content on the particle mixture ranging between 5\% and 12\% (Bertolini et al. 2014).

From each treatment, five specimens were extracted to evaluate mechanical properties (strength modulus and modulus of elasticity) on static bending test and five specimens were selected for internal bond (tension perpendicular to the faces). Physical properties were also determined: apparent density, thickness swelling ( $2 \mathrm{~h}$ and $24 \mathrm{~h}$ ), and water absorption ( $2 \mathrm{~h}$ and $24 \mathrm{~h}$ ) using five specimens. All properties were determined following the Brazilian Standard ABNT NBR 14810 (2018).

To investigate the influence of the factors and the interaction between them on physical and mechanical properties, an analysis of variance (ANOVA), at a level of 5\% of significance, was performed aided by the software Minitab ${ }^{\circledR}$ (Minitab, version 17, State College, PA, USA).

For ANOVA validation $(\alpha=5 \%)$ and Tukey's test $(\alpha=5 \%)$, the normality and homogeneity of the residual distribution were evaluated using the Anderson-Darling test and $\mathrm{F}$ test, respectively. For test formulation, a P-value equal or higher than 0.05 implies the variances between treatments are homogeneous, which validates the ANOVA model. From the Tukey test, 'A' denotes the treatment associated with the highest mean value, 'B' the second highest mean value, and so on, and equal letters imply treatments with statistically equivalent means.

\section{RESULTS AND DISCUSSION}

Table 3 presents the results on granulometric composition according to each treatment.

According to Table 3, fineness module decreased with the increment of bagasse in the mixture, improving the particle amount between $2 \mathrm{~mm}$ and $4 \mathrm{~mm}$ (Sugahara et al. 2019).

Tables 4 [water absorption (WA), thickness swelling (TS), apparent density (AD)] and 5 [strength modulus (MOR), modulus of elasticity (MOE), internal bond (IB)] present the mean values, coefficient of variation $(\mathrm{CV})$, and the result of the Tukey test considering the percentage of sugarcane incorporation. 
Table 3. Resume of Granulometric Composition of Each Treatment

\begin{tabular}{|c|c|c|c|c|c|c|}
\hline \multirow[t]{2}{*}{ Sieve $(\mathrm{mm})$} & $\begin{array}{c}\text { T0 } \\
\mathrm{Ma}- \\
500.10 \mathrm{~g}\end{array}$ & $\begin{array}{c}\mathrm{T} 1 \\
\mathrm{Ma}- \\
502.10 \mathrm{~g}\end{array}$ & $\begin{array}{c}\mathrm{T} 2 \\
\mathrm{Ma}- \\
494.00 \mathrm{~g}\end{array}$ & $\begin{array}{c}\text { T3 } \\
\mathrm{Ma}- \\
503.25 \mathrm{~g}\end{array}$ & $\begin{array}{c}\mathrm{T} 4 \\
\mathrm{Ma}- \\
505.20 \mathrm{~g}\end{array}$ & $\begin{array}{c}\text { T5 } \\
\mathrm{Ma}- \\
521.60 \mathrm{~g}\end{array}$ \\
\hline & MRA (g) & MRA (g) & MRA (g) & MRA (g) & MRA (g) & MRA (g) \\
\hline 6.300 & 0.000 & 0.000 & 0.000 & 0.000 & 0.000 & 0.000 \\
\hline 4.760 & 0.500 & 3.750 & 2.450 & 2.650 & 3.400 & 6.950 \\
\hline 2.380 & 349.3 & 304.35 & 301.50 & 224.64 & 196.10 & 167.15 \\
\hline 1.190 & 102.3 & 119.05 & 96.75 & 104.20 & 94.65 & 96.10 \\
\hline 0.595 & 37.50 & 37.50 & 41.15 & 50.45 & 66.70 & 73.60 \\
\hline 0.297 & 7.400 & 22.85 & 37.15 & 54.80 & 70.80 & 94.40 \\
\hline 0.149 & 0.500 & 7.400 & 11.25 & 42.80 & 46.05 & 53.30 \\
\hline 0.075 & 1.900 & 7.200 & 3.750 & 23.70 & 27.50 & 30.10 \\
\hline $\begin{array}{c}\text { Fineness } \\
\text { Module }\end{array}$ & 4.6 & 4.4 & 4.3 & 3.7 & 3.5 & 3.3 \\
\hline
\end{tabular}

Table 4. Results of Physical Properties

\begin{tabular}{|c|c|c|c|c|c|}
\hline \multirow{2}{*}{ Tr } & $\begin{array}{c}\text { WA 2 h (\%) } \\
\text { (Tukey) } \\
\text { (CV) }\end{array}$ & $\begin{array}{c}\text { WA 24 h (\%) } \\
\text { (Tukey) } \\
\text { (CV) }\end{array}$ & $\begin{array}{c}\text { TS 2 h (\%) } \\
\text { (Tukey) } \\
\text { (CV) }\end{array}$ & $\begin{array}{c}\text { TS 24 h (\%) } \\
\text { (Tukey) } \\
\text { (CV) }\end{array}$ & $\begin{array}{c}\text { AD (g/cm }) \\
\text { (Tukey) } \\
\text { (CV) }\end{array}$ \\
\hline \multirow{2}{*}{ Ref. } & $27.51(\mathrm{~A})$ & $26.92(\mathrm{~A})$ & $28.83(\mathrm{~A})$ & $24.27(\mathrm{~A})$ & $0.76(\mathrm{~A})$ \\
& $(35.78 \%)$ & $(33.98 \%)$ & $(28.91 \%)$ & $(25.64 \%)$ & $(15.97 \%)$ \\
\hline \multirow{2}{*}{1} & $25.73(\mathrm{~A})$ & $25.24(\mathrm{~A})$ & $25.38(\mathrm{~A})$ & $17.06(\mathrm{~A})$ & $0.79(\mathrm{~A})$ \\
& $(33.28 \%)$ & $(32.15 \%)$ & $(27.36 \%)$ & $(14.61 \%)$ & $(13.78 \%)$ \\
\hline \multirow{2}{*}{2} & $24.36(\mathrm{~B})$ & $24.11(\mathrm{~B})$ & $23.12(\mathrm{~B})$ & $18.46(\mathrm{~B})$ & $0.82(\mathrm{~B})$ \\
& $(29.86 \%)$ & $(28.97 \%)$ & $(26.42 \%)$ & $(16.37 \%)$ & $(13.52 \%)$ \\
\hline \multirow{2}{*}{3} & $23.25(\mathrm{~B})$ & $23.13(\mathrm{~B})$ & $22.18(\mathrm{~B})$ & $15.53(\mathrm{~B})$ & $0.77(\mathrm{~B})$ \\
& $(27.81 \%)$ & $(26.97 \%)$ & $(24.48 \%)$ & $(16.49 \%)$ & $(11.93 \%)$ \\
\hline \multirow{2}{*}{4} & $23.12(\mathrm{~B})$ & $22.85(\mathrm{~B})$ & $21.53(\mathrm{~B})$ & $17.93(\mathrm{~B})$ & $0.79(\mathrm{~B})$ \\
& $(27.16 \%)$ & $(26.97 \%)$ & $(23.45 \%)$ & $(14.61 \%)$ & $(10.57 \%)$ \\
\hline \multirow{2}{*}{5} & $23.29(\mathrm{~B})$ & $23.18(\mathrm{~B})$ & $20.15(\mathrm{~B})$ & $15.10(\mathrm{~B})$ & $0.71(\mathrm{~B})$ \\
& $(26.96 \%)$ & $(26.58 \%)$ & $(23.53 \%)$ & $(16.42 \%)$ & $(9.37 \%)$ \\
\hline
\end{tabular}

Table 5. Results of Mechanical Properties

\begin{tabular}{|c|c|c|c|}
\hline \multirow{2}{*}{ Tr } & $\begin{array}{c}\text { MOR (MPa) } \\
\text { (Tukey) } \\
\text { (CV) }\end{array}$ & $\begin{array}{c}\text { MOE (MPa) } \\
\text { (Tukey) } \\
\text { (CV) }\end{array}$ & $\begin{array}{c}\text { IB (MPa) } \\
\text { (Tukey) } \\
\text { (CV) }\end{array}$ \\
\hline \multirow{2}{*}{ Ref } & $7.40(\mathrm{~B})$ & $1108(\mathrm{~B})$ & $1.12(\mathrm{~B})$ \\
& $(5.68 \%)$ & $(35.15 \%)$ & $(25.39 \%)$ \\
\hline \multirow{2}{*}{1} & $8.57(\mathrm{~A})$ & $1821(\mathrm{~A})$ & $1.11(\mathrm{~B})$ \\
& $(4.38 \%)$ & $(32.54 \%)$ & $(23.38 \%)$ \\
\hline \multirow{2}{*}{2} & $9.13(\mathrm{~A})$ & $1959(\mathrm{~A})$ & $1.21(\mathrm{~A})$ \\
& $(3.58 \%)$ & $(31.56 \%)$ & $1.25 \%(\mathrm{~A})$ \\
\hline \multirow{2}{*}{3} & $11.44(\mathrm{~A})$ & $(29.41 \%)$ & $(20.89 \%)$ \\
\hline \multirow{2}{*}{4} & $(2.35 \%)$ & $1936(\mathrm{~A})$ & $1.20(\mathrm{~A})$ \\
& $9.29(\mathrm{~A})$ & $(28.36 \%)$ & $(19.38 \%)$ \\
\hline \multirow{2}{*}{5} & $(1.13 \%)$ & $2034(\mathrm{~A})$ & $(1.22(\mathrm{~A})$ \\
& $11.09(\mathrm{~A})$ & $(27.38 \%)$ & \\
\hline
\end{tabular}


Observing the apparent density, the results ranged between $0.71 \mathrm{~g} / \mathrm{cm}^{3}$ and 0.82 $\mathrm{g} / \mathrm{cm}^{3}$, close to the values obtained by Oliveira et al. (2016) $\left(0.62 \mathrm{~g} / \mathrm{cm}^{3}\right)$ using Pinus sp. and Eucalyptus residues. Fiorelli et al. (2013) reached values between $0.88 \mathrm{~g} / \mathrm{cm}^{3}$ and 0.95 $\mathrm{g} / \mathrm{cm}^{3}$ using only sugarcane bagasse, which was higher than obtained by this research. All these researches used castor oil-based PU resin.

Checking the physical properties (Table 4), it must be pointed out that the sugarcane bagasse incorporation in panels significantly reduced the values of physical properties (WA and TS) and their CV, indicating the combination of two residues brought dimensional stability to the particleboards with the increase of bagasse proportion. In view of mechanical properties (Table 5), the bagasse residue significantly increased the MOR, MOE, and IB values and reduced their variability, providing a better performance in further use.

The statistical analysis (Tukey test) demonstrated the good influence of use of industrial timber sawdust on particleboard. Considering the results presented on Tables 4 and 5, most of treatments were classified on a different mean value when compared the reference treatment, enhancing physical and mechanical properties of particleboards.

In the literature, there have been no studies using sugarcane bagasse and industrial sawdust from tropical hardwood species and PU resin, making it impossible to directly compare the results obtained in the present research. Also, it must be pointed out that this is an exploratory study, which aimed to evaluate the performance of industrial timber sawdust waste on particleboards. The increase of performance on particleboards with sawn wood and sugarcane bagasse can be explained by the granulometry of sawdust, which contains large number of fines. Further studies may focus on the behavior of fines on physical and mechanical properties.

Table 6 presents the standard requisites used for MDP.

Table 6. Standard Requisites

\begin{tabular}{|c|c|c|c|c|c|c|}
\hline Standard & $\begin{array}{c}\text { Thickness } \\
(\mathbf{m m})\end{array}$ & $\begin{array}{c}\text { Apparent } \\
\text { Density }\left(\mathbf{g} / \mathbf{c m}^{3}\right)\end{array}$ & $\begin{array}{c}\text { MOR } \\
(\mathbf{M P a})\end{array}$ & $\begin{array}{c}\text { MOE } \\
(\mathbf{M P a})\end{array}$ & $\begin{array}{c}\text { IB } \\
(\mathbf{M P a})\end{array}$ & $\begin{array}{c}\text { TS 24 } \\
\mathbf{h}(\%)\end{array}$ \\
\hline $\begin{array}{c}\text { NBR 14810 } \\
(2018)\end{array}$ & $6-13$ & - & 11 & 1800 & 0.35 & 22 \\
\hline $\begin{array}{c}\text { ANSI A 208.1 } \\
(2009)\end{array}$ & - & $>0.8$ & 16.5 & 2400 & 0.90 & 8 \\
\hline $\begin{array}{c}\text { CS 236:66 } \\
(1968)\end{array}$ & - & $>0.8$ & 16.8 & 2500 & 0.45 & 35 \\
\hline
\end{tabular}

Considering the values presented in Table 6, Treatments 3 and 5 fully met the requirements of Brazilian Standard ABNT NBR 14810 (2018). Considering the Standard ANSI A 208.1 (2009) and CS 236:66 (1968), Treatments 1 and 2 only met AD and IB requirements.

Evaluating physical and mechanical properties of Treatment 5 (T5) and other treatments, it can be possible to affirm T5 is the best condition to produce particleboards with sugarcane bagasse and industrial sawdust from tropical hardwoods according to the results presented, demanding more studies to achieve the optimum proportion between industrial waste and bagasse.

According to Brazilian Standard ABNT NBR 14810 (2018), T5 panels produced in this research were classified as type P2, nonstructural panels for inner use on dry conditions. Such conditions may enable their use as a wall coating to improve thermal and 
acoustic performance for buildings, being a greener alternative to the use of glass wool, rock wool, and elastomeric foams, saving resources and reusing waste, demanding further studies to evaluate this possibility.

\section{CONCLUSIONS}

1. Part of the particleboards made of industrial sawmill and sugarcane bagasse met the standard requirements, with Treatment 5 being the best adjustment between the residues to produce wood panels in this research.

2. The incorporation of bagasse promoted an improvement on properties of panels made with timber residue and provided dimensional stability to the panels, reducing moisture content.

3. Treatment 5 panels were classified as P2 type by the Brazilian Standard, a nonstructural panel for indoor use in dry conditions, demonstrating the possibility of their use as coating to improve thermal and acoustic performance for buildings.

\section{ACKNOWLEDGMENTS}

The authors thank the National Council for Scientific and Technological Development $(\mathrm{CNPq})$ and the Coordination for the Improvement of Higher Education Personnel (CAPES) for the support provided.

\section{REFERENCES CITED}

ABNT NBR 14810 (2018). "Chapas de madeira aglomerada - NBR 14810 [Medium density particleboards]," Associação Brasileira de Normas Técnicas [Brazilian Association of Technical Standards], Rio de Janeiro, Brazil.

Akgül, M., Uner, B., Çamlibel, O., and Ayata, U. (2017). "Manufacture of medium density fiberboard (MDF) panels from agribased lignocellulosic biomass," Wood Research 62(4), 615-624.

ANSI CS 236-66 (1968). "Mat formed wood particleboard," American National Standards Institute, New York, NY, USA.

ANSI A 208.1 (2009). "Particleboards physical \& mechanical properties requirements," American National Standards Institute, New York, NY, USA.

Beech, E., Rivers, M., Oldfield, S., and Smith, P. P. (2017). "GlobalTreeSearch: The first complete global database of tree species and country distributions," Journal of Sustainable Forestry 36(5), 454-489. DOI: 10.1080/10549811.2017.1310049

Bertolini, M. D. S., Galvaõ De Morais, C. A., Lahr, F. A. R., Freire, R. T. S., Panzera, T. H., and Christoforo, A. L. (2019a). "Particleboards from CCB-treated Pinus sp. wastes and castor oil resin: Morphology analyses and physical-mechanical properties," Journal of Materials in Civil Engineering 31(11), 1-8. DOI: 10.1061/(ASCE)MT.1943-5533.0002929

Bertolini, M. d. S., De Morais, C. A. G., Christoforo, A. L., Bertoli, S. R., Dos Santos, W. N., and Lahr, F. A. R. (2019b). "Acoustic absorption and thermal insulation of 
wood panels: Influence of porosity," BioResources 14(2), 3746-3757. DOI:

10.15376/biores.14.2.3746-3757

Bertolini, M. S., Nascimento, M. F., Christoforo, A. L., and Lahr, F. A. R. (2014).

"Paineis de partículas provenientes de rejeitos de Pinus sp. tratado com preservante CCA e resina derivada de biomassa [Particleboards using Wastes from CCA-Treated Pinus sp. and Resin from Biomass]," Revista Árvore 38(2), 339-346. DOI: 10.1590/S0100-67622014000200014

Christoforo, A. L., Aftimus, B. H. C., Panzera, T. H., Machado, G. d. O., and Lahr, F. A. R. (2017). "Physico-mechanical characterization of the Anadenanthera colubrina wood specie," Engenharia Agricola 37(2), 376-384. DOI: 10.1590/1809-4430Eng.Agric.v37n2p376-384/2017

Companhia Nacional de Abastecimento - CONAB (2019). "Acompanhamento da Safra Brasileira [Monitoring the Brazilian Crop]," Companhia Nacional de Abastecimento 5(4), 1-113. DOI:

CS 236-66 (1968). "Mat formed wood particleboard," Commercial Standard, Geneva, Switzerland.

Ferro, F. S., Icimoto, F. H., De Souza, A. M., De Almeida, D. H., Christoforo, A. L., and Lahr, F. A. R. (2015). "Produção de paineis de partículas orientadas (OSB) com Schizolobium amazonicum e resina poliuretana à base de óleo de mamona [Production of Oriented Strand Board (OSB) with Schizolobium amazonicum and castor oil based polyurethane resin]," Scientia Forestalis [Forest Sciences] 43(106), 313-320. DOI:

Fink, G., Kohler, J., and Brandner, R. (2018). “Application of European design principles to cross laminated timber," Engineering Structures 171, 934-943. DOI:

10.1016/j.engstruct.2018.02.081

Fiorelli, J., Bueno, S. B., and Cabral, M. R. (2019). "Assessment of multilayer particleboards produced with green coconut and sugarcane bagasse fibers," Construction and Building Materials 205, 1-9. DOI:

10.1016/j.conbuildmat.2019.02.024

Fiorelli, J., Galo, R. G., Castro, Jr., S. L., Belini, U. L., Lasso, P. R. O., and Savastano, H. (2018). "Multilayer particleboard produced with agroindustrial waste and Amazonia vegetable fibres," Waste and Biomass Valorization 9(7), 1151-1161. DOI: 10.1007/s12649-017-9889-x

Fiorelli, J., Sartori, D. d. L., Cravo, J. C. M., Savastano, Jr., H., Rossignolo, J. A., Nascimento, M. F. d., and Lahr, F. A. R. (2013). "Sugarcane bagasse and castor oil polyurethane adhesive-based particulate composite," Materials Research 16(2), 439446. DOI: 10.1590/S1516-14392013005000004

Hazrati-Behnagh, M., Zarea-Hosseinabadi, H., Daliri-Sosefi, M., Abginehchi, Z., and Hemmati, A. (2016). "Mechanical and insulating performances of ultralight thick particleboard from sugarcane residues and woods planer shaving," European Journal of Wood and Wood Products 74(2), 161-168. DOI: 10.1007/s00107-015-0989-7

Hiziroglu, S., Jarusombuti, S., Bauchongkol, P., and Fueangvivat, V. (2008). "Overlaying properties of fiberboard manufactured from bamboo and rice straw," Industrial Crops and Products 28(1), 107-111. DOI: 10.1016/j.indcrop.2008.01.002

Hofsetz, K., and Silva, M. A. (2012). "Brazilian sugarcane bagasse: Energy and nonenergy consumption," Biomass and Bioenergy 46, 564-573. DOI:

10.1016/j.biombioe.2012.06.038

Ihnát, V., Lübke, H., Russ, A., and Borůvka, V. (2017). "Waste agglomerated wood 
materials as a secondary raw material for chipboards and fibreboards Part II. Preparation and characterization of wood chips in terms of their reuse," Wood Research 62(1), 45-56.

Indústria Brasileira de Árvores (IBÁ) (2017). "Relatório 2017 [2017 Report]," Indústria Brasileira de Árvores - IBÁ 80. DOI: 10.1017/CBO9781107415324.004

Khazaeian, A., Ashori, A., and Dizaj, M. Y. (2015). "Suitability of sorghum stalk fibers for production of particleboard," Carbohydrate Polymers 120, 15-21. DOI: 10.1016/j.carbpol.2014.12.001

Kusumah, S. S., Umemura, K., Guswenrivo, I., Yoshimura, T., and Kanayama, K. (2017). "Utilization of sweet sorghum bagasse and citric acid for manufacturing of particleboard II: Influences of pressing temperature and time on particleboard properties," Journal of Wood Science 63(2), 161-172. DOI: 10.1007/s10086-0161605-0

Lima, F. O., Silva, L. C. L., Campos, C. I. D., Christoforo, A. L., and Lahr, F. A. R. (2018). "Influência do tempo de prensagem em propriedades físicas e mecânicas de painéis MDP [Pressing time Influence on physical and mechanical properties of MDP panels]," Scientia Forestalis 46(119), 387-393. DOI: 10.18671/scifor.v46n119.06

Melo, R. R., Stangerlin, D. M., Santana, R. R. C., and Pedrosa, T. D. (2014). "Physical and mechanical properties of particleboard manufactured from wood, bamboo and rice husk," Materials Research 17(3), 682-686. DOI: 10.1590/S151614392014005000052

Muttil, N., Ravichandra, G., Bigger, S. W., Thorpe, G. R., Shailaja, D., and Singh, S. K. (2014). "Comparative study of bond strength of formaldehyde and soya based adhesive in wood fibre plywood," Procedia Materials Science 6, 2-9. DOI: 10.1016/j.mspro.2014.07.002

Nascimento, M. F. d, Lahr, F. A. R., Christoforo, A. L., Bertolini, M. d S., Fiorelli, J., and Silva, M. R. d. (2016). "Painéis de partículas homogêneas fabricados com resíduos lignoceluósicos e resina alternativa para aplicação em pisos [Homogeneous particleboards manufactured with lignocellulosic waste and alternative resin for floor applications]," Scientia Forestalis 44(112), 1001-1007. DOI: 10.18671/scifor.v44n112.21

Oliveira, S. L., Mendes, R. F., Mendes, L. M., and Freire, T. P. (2016). "Particleboard panels made from sugarcane bagasse: Characterization for use in the furniture industry," Materials Research 19(4), 914-922. DOI: 10.1590/1980-5373-MR-20150211

Paiva, A., Pereira, S., Sá, A., Cruz, D., Varum, H., and Pinto, J. (2012). "A contribution to the thermal insulation performance characterization of corn cob particleboards," Energy and Buildings 45, 274-279. DOI: 10.1016/j.enbuild.2011.11.019

Pan, Z., Zheng, Y., Zhang, R., and Jenkins, B. M. (2007). "Physical properties of thin particleboard made from saline eucalyptus," Industrial Crops and Products 26(2), 185-194. DOI: 10.1016/j.indcrop.2007.03.006

Ribeiro, D. P., Vilela, A. P., Silva, D. W., Napoli, A., and Mendes, R. F. (2019). "Effect of heat treatment on the properties of sugarcane bagasse medium density particleboard (MDP) panels," Waste and Biomass Valorization. DOI: 10.1007/s12649-019-00882-9

Sam-Brew, S., and Smith, G. D. (2017). "Flax shive and hemp hurd residues as alternative raw material for particleboard production," BioResources 12(3), 57155735. DOI: $10.15376 /$ biores.12.3.5715-5735 
Shirosaki, R. K., Almeida, T. H. d., Panzera, T. H., Christoforo, A. L., and Lahr, F. A. R. (2018). "Caracterização de painéis de partículas de média densidade feitos com resina poliuretana monocomponente à base de mamona [Characterization of medium density particleboards made with monocomponent castor oil-based polyurethane resin]," Ambiente Construído 19(1), 37-43. DOI: 10.1590/s1678-86212019000100291

Silva, D. W., Farrapo, C. L., Ribeiro, D. P., Mendes, R. F., Mendes, L. M., and Scolforo, J. R. S. (2015). "MDP com partículas de eucalipto e palha de milho [MDP with particles of eucalyptus and corn straw]," Scientia Forestalis 43(108), 853-862. DOI: 10.18671/scifor.v43n108.10

Souza, A. M., Varanda, L. D., Macedo, L. B. d., Almeida, D. H., Bertolini, M. d. S., Christoforo, A. L., and Lahr, F. A. R. (2014). "Mechanical properties of OSB wood composites with resin derived from a renewable natural resource," International Journal of Composite Materials 4(3), 157-161. DOI:

10.5923/j.cmaterials.20140403.01

Steege, H. T., Vaessen, R. W., Cárdenas-López, D., Sabatier, D., Antonelli, A., Oliveira, S. M., Pitman, N. C. A., Jørgensen, P. M., and Salomão, R. P. (2016). "The discovery of the Amazonian tree flora with an updated checklist of all known tree taxa," Scientific Reports 6, Article number 29549. DOI: 10.1038/srep29549

Sugahara, E. S., Da Silva, S. A. M., Laura, A., Buzo, S. C., De Campos, C. I., Morales, E. A. M., Ferreira, B. S., Azambuja, M. D. A., Lahr, F. A. R., and Christoforo, A. L. (2019). "High-density particleboard made from agro-industrial waste and different adhesives," BioResources 14(3), 5162-5170. DOI: 10.15376/biores.14.3.5162-5170

Valarelli, I. D., Batistelle, R. A. G., Branco, L. A. M. N., Chahud, E., Christoforo, A. L., Rocco Lahr, F. A., and Bezerra, B. S. (2014). "Evaluation of bamboo particleboards produced with urea-formaldheyde resin," Advanced Materials Research 1025-1026, 432-435. DOI: 10.4028/www.scientific.net/AMR.1025-1026.432

Varanda, L. D., Nascimento, M. F. d., Christoforo, A. L., Silva, D. A. L., and Lahr, F. A. R. (2013). "Oat hulls as addition to high density panels production," Materials Research 16(6), 1355-1361. DOI: 10.1590/s1516-14392013005000131

Zhou, X., and Pizzi, A. (2014). "Pine tannin based adhesive mixes for plywood," International Wood Products Journal 5(1), 27-32. DOI: 10.1179/2042645313Y.0000000043

Article submitted: March 4, 2020; Peer review completed: April 26, 2020; Revised version received: April 28, 2020; Accepted: April 30, 2020; Published: May 7, 2020. DOI: $10.15376 /$ biores. 15.3.4753-4762 